A) Control

Clade A/AE/AG

Clade B

Clade C

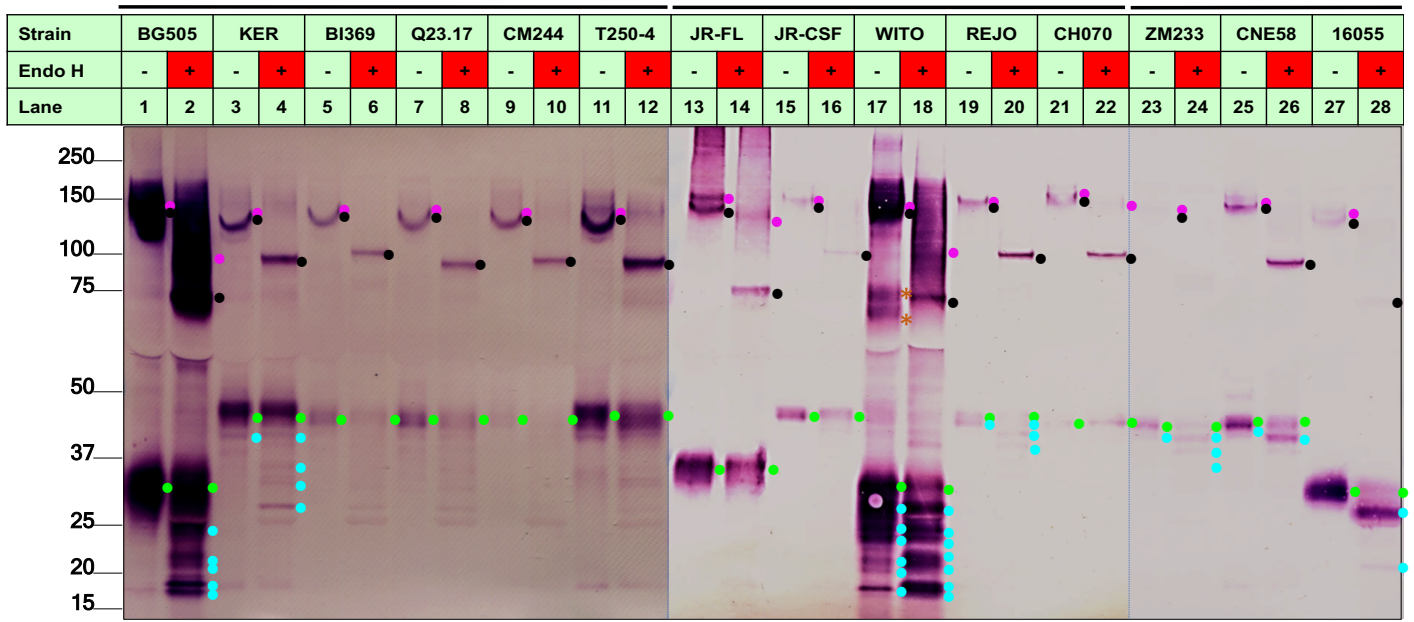

\title{
B) B4GalT1
}

Clade A/AE/AG

Clade B

Clade C

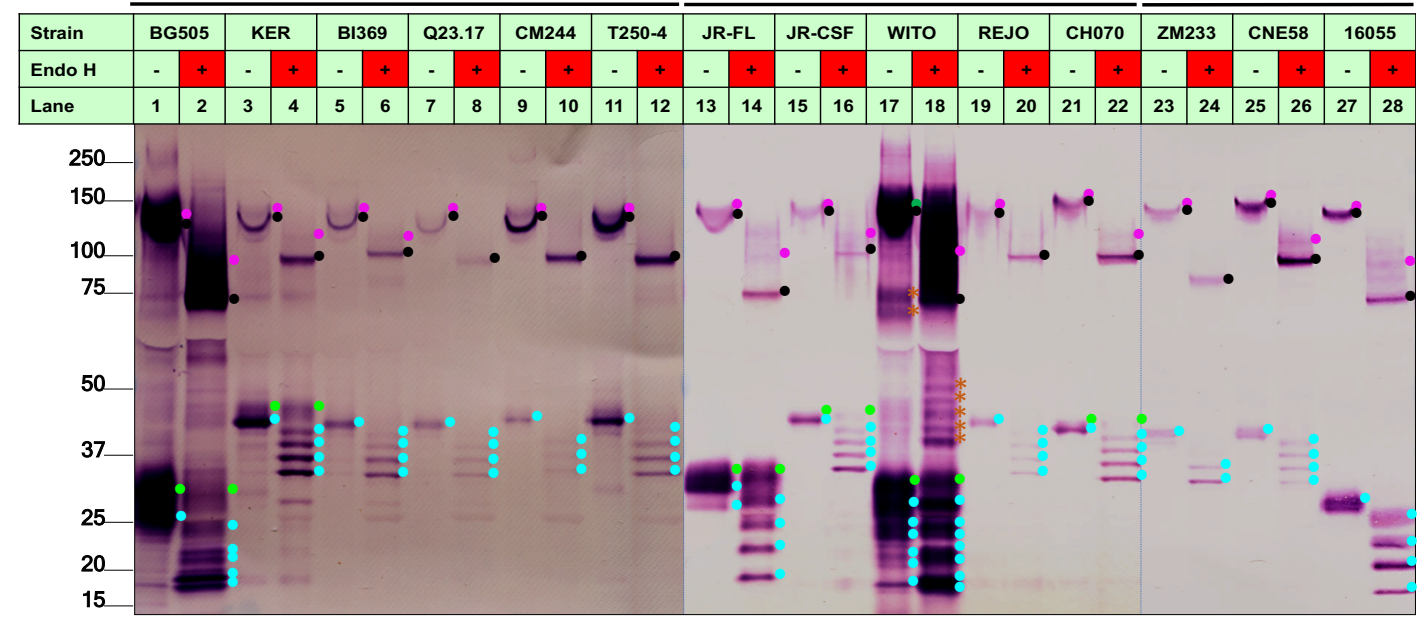

